\title{
Učestalost i oblici suradnje odgojitelja i roditelja u katoličkim vrtićima u odnosu na javne i privatne dječje vrtiće u Zadarskoj županiji
}

\author{
Marijana Mohorić*, Diana Nenadić-Bilan**
}

\begin{abstract}
Sažetak
U radu se polazi od rezultata brojnih istraživanja o potrebi $i$ važnosti uspostave suradničkih odnosa između odgojitelja i roditelja. Rezultati navedenih istraživanja ukazuju na nezamjenljivi doprinos roditeljske uključenosti cjelokupnoj dobrobiti djece, kao i kvaliteti života i rada predškolske ustanove. Polazeći od potrebe aktivnoga i intenzivnoga uključivanja roditelja kao ravnopravnih suradnika u ostvarivanje misije i zadaća dječjega vrtića, u radu su prezentirani rezultati istraživanja provedenoga na uzorku od tri javna gradska dječja vrtića, tri privatna dječja vrtića te tri katolička dječja vrtića u Zadarskoj županiji. Ispitani su stavovi odgojitelja u vezi s učestalosti odaziva roditelja na suradnju, zastupljenih oblika suradnje s roditeljima te uočenih prepreka u ostvarivanju suradničkih odnosa. Dobiveni rezultati istraživanja ukazuju na sličnosti, ali i razlike u navedenim stavovima s obzirom na vrstu predškolske ustanove. Podatci prezentirani u radu potiču na daljnja istraživanja negativnih stavova koji ometaju uspostavu kvalitetnije suradnje s roditeljima te promišljanje učinkovitijih oblika suradnje koji bi odgovarali potrebama suvremene obitelji.
\end{abstract}

Ključne riječi: suradnja, roditelji, odgojitelji, katolički vrtići

\section{Uvod}

Kvaliteta realizacije kurikuluma ranoga i predškolskoga odgoja ovisi i o realizaciji suradnje, odnosno partnerstva s obiteljima djece. Naime, kao ključna područja kvalitete navode se strategija ustanove, organizacijsko vođenje ustanove, kultura ustanove, prostorno-materijalni i tehnički uvjeti rada, zdravstvenohigijenski uvjeti rada i sigurnost, kurikulum i odgojno-obrazovni proces, ljudski

* Mr. sc. Marijana Mohorić, Teološko-katehetski odjel Sveučilišta u Zadru. Adresa: Dr. Franje Tuđmana 24i, 23000 Zadar, Hrvatska. E-adresa: marijana.scj@gmail.com

** Doc. dr. sc. Diana Nenadić-Bilan, Odjel za izobrazbu učitelja i odgojitelja Sveučilišta u Zadru. Adresa: Dr. Franje Tuđmana 24i, 23000 Zadar, Hrvatska. E-adresa: dnbilan@gmail.com 
resursi, suradnja s užom i širom društvenom zajednicom te proces praćenja i vrednovanja (Slunjski et al., 2012, 34). U svakoj ustanovi uspostavlja se mreža različitih složenih i osjetljivih interakcijskih procesa između svih sudionika (djece, odgojitelja, roditelja, ostalih djelatnika ustanove, vanjskih suradnika, predstavnika ustanova iz lokalne zajednice), a čiji bi optimalni rezultat trebao biti suradnički ili partnerski odnos svih uključenih. Suradnička kultura je važna dimenzija organizacije ustanove za rani i predškolski odgoj i obrazovanje, a stvara se zajedničkom sukonstrukcijom svih djelatnika ustanove, djece, roditelja i vanjskih suradnika. Izrazitu suradničku kulturu moguće je iščitavati u praksi koju označava

snažna povezanost, međusobna ovisnost akcija i zajednička odgovornost (npr. za svu djecu, prostor i cjelokupan odgojno-obrazovni proces u ustanovi), zajednički doprinos i angažiranost u procesu unapređivanja odgojno-obrazovne, prakse i kurikuluma, spremnost na sudjelovanje u procesu promjena i pomoć u „teškim” situacijama, spremnost na davanje informacije suradnicima i primanje povratne informacija od njih (Slunjski et al., 2012, 49).

Brojni autori, u odnosu na ostale dimenzije organizacije odgojno-obrazovne djelatnosti, upravo naglašavaju važnost suradničke dimenzije u predškolskoj ustanovi.

\section{Suradnička dimenzija organizacije odgojno-obrazovne djelatnosti}

\subsection{Pojam i obilježja suradnje}

U pojmovnom smislu moguće je uočiti raznolikost uporabe termina. Nailazimo na brojne termine: sudjelovanje (participacija), partnerstvo, zajedništvo, uključenost, suradnja (kooperacija) i dr. Iako navedeni termini imaju pozitivne konotacije, njihovo značenje nije sasvim jasno definirano. Naime, navedeni nazivi kondenziraju specifične sadržaje u određenoj riječi ili izrazu, pa tijekom vremena »riječi zadobivaju pretpostavljena značenja koja se rijetko kritički razmatraju « (Vincent, 1996, 3). ${ }^{1}$

U relevantnoj literaturi ukazuje se na potrebu razlikovanja termina suradnja ili partnerstvo, pri čemu se partnerstvo određuje kao najviša razina suradničkih odnosa. U odnosu na suradnju, u kojoj suradnici mogu biti u određenom hijerarhijskom odnosu, u partnerstvu se očituje ravnopravnost svih uključenih subjekata. Wit $(2005,9)$ definira partnerstvo kao smislenu suradnju roditelja i ustanove u kojoj obje strane međusobno savjetuju i daju potporu jedni drugima. Prema Ljubetić $(2014,3)$, partnerstvo određuju termini: odnos (suradnja), odgovornost (zajednička), zajednički cilj (specifičnost), distribucija moći (ravnopravnost), kvalitetna komunikacija (harmonija, pregovaranje, konsenzus), energija (djelovanje) uložena u ostvarivanje postavljenoga cilja.

Oostdam i Hooge $(2013,342)$ ukazuju na krovni termin aktivno roditeljstvo, koji označava različite oblike svjesne i proaktivne roditeljske uključenosti. Autori

1 Citati preuzeti iz izvornika na stranim jezicima prijevod su autora članka. 
su definirali okvir aktivnoga roditeljstva u kojem razlikuju tri vrste partnerstva: socijalno, edukacijsko i formalno partnerstvo. U socijalnom partnerstvu roditelji i odgojitelji surađuju u svim aktivnostima koje se odvijaju izvan ustanove. Epstein $(2001,67)$ naziva tu vrstu partnerstva suradnjom sa zajednicom. Oostdam i Hooge $(2013,344)$ definiraju formalno partnerstvo kao uključenost roditelja u sve aktivnosti ustanove (primjerice roditeljska ispomoć u organizaciji izleta, priredbi, svečanosti i sl.). Središnji dio aktivnoga roditeljstva čini tzv. edukacijsko partnerstvo, koje je usmjereno prema pomaganju i unaprjeđivanju procesa učenja djece. Edukacijsko partnerstvo uključuje pedagoško i didaktičko partnerstvo. Autori određuju pedagoško partnerstvo kao suradnju odgojitelja i roditelja kako bi se izbjegle situacije u kojima su obiteljsko i institucionalno okruženje odvojeni svjetovi, pa primjerice roditelji u odnosu na odgojitelje koriste drukčije odgojne postupke. Didaktičko partnerstvo smjera prema osnaživanju obrazovnih ishoda, pa roditelji mogu uz odgojiteljevu potporu još više doprinositi obrazovnim postignućima i procesima učenja djece.

\subsection{Polazišta i dobrobiti suradnje odgojitelja i roditelja}

Život i djelovanje odvija se uključivanjem u različite društvene skupine, odnosno uspostavom interakcijskih odnosa s drugima. »Životni su procesi u svom temeljnom karakteru interaktivni pa stoga naša osobnost u svojoj prirodi nije neovisna. Mi živimo u odnosima i od odnosa (Balaić, 2011, 353). Zajedništvo upućuje na odnose uzajamnosti i dijeljenja zajedničke vizije i misije djelovanja, kao i sudjelovanje u izgradnji zajedničkih vrijednosti.

Rad na uspostavi zajedništva između roditelja i odgojitelja preduvjet je cjelovitoj potpori djetetu, ali i potpori njihovim obiteljima. Bez uzajamnoga otvaranja i kontinuirane komunikacije između roditelja i svih djelatnika ustanove djeci se pruža samo parcijalna potpora, što ne može rezultirati njihovom cjelovitom dobrobiti. S obzirom na to da su odnosi među ljudima često krhki i podložni različitim vrstama ugroza, valja se senzibilizirati u prepoznavanju osobnih i tuđih ograničenja u uspostavi kvalitetnih odnosa, ali i razvijati svijest o prihvaćanju drugoga i drugačijega. Ukazujući na važnost izgradnje pozitivnih zajednica ili institucija, Peterson $(2006,275)$ navodi značajke takvih zajednica: svrhovitost (zajednička vizija o ciljevima institucije), sigurnost (zaštita), pravednost (poštena pravila za nagrađivanje i kažnjavanje), humanost (uzajamna briga) i poštovanje (poštovanje prema svima u instituciji, bez obzira na njihov položaj).

Iako partnerstvo podrazumijeva jednakost i ravnopravnost subjekata, ono istovremeno ne znači i jednakost startnih pozicija, znanja, interesa, vještina, očekivanja i dr. U tom smislu Oostdam i Hooge $(2013,347)$ upozoravaju na razliku u emocionalnoj uključenosti suradnika — roditelji su emocionalno više uključeni u odnosu na odgojitelje. Odgojitelji iskazuju viši stupanj profesionalnosti, pa s time i emocionalne distance. Govoreći o emocionalnoj povezanosti, Hargrave et al. $(2007,151)$ razlikuju tzv. vodoravnu i okomitu odanost. Autori odnosu između roditelja i djece atribuiraju okomitu odanost — odanost onima koji su nam dali temeljne vrijednosti, sve do dara života. S druge strane, vodoravna odanost se 
očituje u uzajamnim odnosima u koje se ulazi po osobnom izboru, koji su obzirni i osjetljivi, a koji mogu imati i svoj završetak. Oostdam i Hooge $(2013,343)$ upozoravaju kako »jednaki status u partnerstvu ne treba prikriti činjenicu da roditelji i škola imaju različita očekivanja s obzirom na njihovu odgovornost, a i njihova mišljenja o optimumu uvjeta za djetetov razvoj i učenje se mogu bitno razlikovati«. Autori smatraju kako se navedeno osobito očituje u situacijama kada se roditeljska emocionalna uključenost suoči s profesionalnim i nepristranim stavom odgojitelja. Visoka razina profesionalnosti i etičnosti, kao i otvorenosti i fleksibilnosti odgojitelja u komunikaciji s roditeljima doprinosi uzajamnomu prihvaćanju i povjerenju.

U ostvarivanju partnerskih odnosa roditelji i odgojitelji ne dijele uvijek jednaka polazišta, kao ni jednaku odgovornost. Oostdam i Hooge $(2013,343)$ ukazuju na primarnu odgovornost odgojno-obrazovne institucije u obnašanju odgovornosti, u motivaciji roditelja te uspostavi pravila koja se odnose na partnerstvo. U tom smislu valja, prije svega, identificirati potrebe i očekivanja roditelja. Stoga autori predlažu odgovoriti na sljedeća pitanja: Što napraviti ako roditelji odbiju preuzeti ulogu ravnopravnoga partnera? Je li prihvatljivo ako se roditelj rijetko odaziva ili pojavljuje? Koji je minimum zahtjeva u vezi s roditeljskom uključenosti? (Oostdam i Hooge, 2013, 344).

Odnos sa svakom pojedinačnom obitelji jedinstven je i neponovljiv ili, točnije, odnos sa svakim pojedinačnim ocem ili majkom jest drugačiji. Svaki odnos vrjednuje se posebnošću, tj. osobnošću sudionika. A osobnost je »jedinstvenost koju se ne može generalizirati ni ponoviti« (Rolnick, 2012, 19). Roditelji se međusobno razlikuju s obzirom na brojne karakteristike (od socio-demografskih do karakternih), što može utjecati na njihovu razinu uključenosti u partnerske odnose s roditeljima.

Dobrobiti partnerstva ne treba posebno obrazlagati. U obrazloženju pozitivnih ishoda roditeljske uključenosti u realizaciji predškolskoga kurikuluma, Henrich navodi obiteljsku dobrobit, pozitivne odnose između roditelja i djece, obitelj kao cjeloživotnoga edukatora, obitelj kao učenike, sudjelovanje obitelji u procesu tranzicije djece u školu, uspostavu obiteljskih veza s vršnjacima i zajednicom te osnaživanje obitelji kao odvjetnika i lidera (Henrich, 2013, 254). Prema Australian Children's Education and Care Quality Authority (2016, 2), dobrobiti uspostave partnerskih odnosa s roditeljima moguće je prepoznati u nekoliko područja. Dobrobiti za djecu su: iskustvo kontinuiteta učenja; uključenost djece u procese donošenja odluka; doživljaj prihvaćanja i priznavanja njihovih snaga i vrijednosti; snažnija iskustva pripadanja. Među dobrobitima za obitelji ističu se: osjećaj vrijednosti i poštivanja; bolje razumijevanje učenja i razvoja djece; osjećaj potpore i osnaživanja u obnašanju roditeljske uloge; veće povjerenje u ustanovu ranoga i predškolskoga odgoja i obrazovanja; međusobno pomaganje i umrežavanje obitelji u zajedničku mrežu potpore. Dobrobiti za odgojitelje su brojne: odgojitelji uče od roditelja, njihovih informacija i vještina; informacije dobivene od roditelja su u funkciji potpore djetetovu razvoju i odgoju; bolje razumiju probleme koje roditelji imaju; primaju povratne informacije od roditelja kako 
bi mogli djelotvornije vrjednovati djelatnosti ustanove. Tako ustanova za rani i predškolski odgoj i obrazovanje postaje središtem partnerskih odnosa ne samo između svih sudionika odgojno-obrazovnoga procesa, nego i s institucijama u lokalnoj zajednici.

\section{Kurikulum ranoga i predškolskoga odgoja i obrazovanja}

\subsection{Roditelji kao suradnici u realizaciji kurikuluma ranoga i predškolskoga odgoja i obrazovanja}

Kvalitetna suradnja roditelja i odgojitelja važna je dimenzija organizacije odgojno-obrazovne djelatnosti u predškolskim ustanovama te bitna karakteristika humanističke koncepcije predškolskoga odgoja. Zakonski okvir u tom smislu donosi obvezu o nužnosti potpore obiteljskoga odgoja i uspostave djelatne suradnje s roditeljima i neposrednim dječjim okruženjem u provedbi programa odgoja i obrazovanja.

U kontekstu govora o odgoju i obrazovanju usmjerenom na dijete u Nacionalnom okvirnom kurikulumu istaknuto je: »Kvalitetno odgojno-obrazovno djelovanje predškolske ustanove i škole podrazumijeva redovitu i trajnu suradnju s roditeljima/skrbnicima u smislu jasno podijeljene odgovornosti glede ostvarivanja ciljeva odgoja i obrazovanja u školi« (Fuchs et al., 2011, 17). Redovitost i trajnost suradnje s roditeljima zahtijeva promjenu metoda i oblika rada, odnosno ukazuje na potrebu interaktivnoga pristupa koji počiva na otvorenom dijalogu, izboru i suodlučivanju. Takva suradnja pretpostavka je kvalitetnoga ostvarivanja odgojno-obrazovnoga rada na svim razinama, pa tako i u ranom i predškolskom odgoju i obrazovanju. Kako se ističe u spomenutom dokumentu: »Preduvjet za valjano djelovanje ustanova ranoga i predškolskoga odgoja i obrazovanja usmjereno je na razumijevanje i prihvaćanje roditelja/skrbnika kao ravnopravnih sudionika u institucijskome odgojno-obrazovnomu radu « Fuchs et al., 2011, 18). U tom smislu Nacionalni kurikulum za rani i predškolski odgoj i obrazovanje ukazuje na potrebu prihvaćanja, poštivanja, ohrabrivanja, podržavanja, aktivnoga slušanja roditelja/skrbnika kao ravnopravnih članova vrtića — partnera »koji ustanovu obogaćuju svojim individualnim posebnostima te svojom vlastitom kulturom i time pridonose kvaliteti ustanove u cjelini« (Slunjski et al., 2014, 4). Taj doprinos u službi je višega cilja same suradnje: "primjereno odgovoriti na individualne i razvojne potrebe djeteta i osigurati potporu njegovu cjelovitom razvoju « (Slunjski et al., 2014, 14). Navedeni cilj zahtijeva obostranu spremnost i kvalitetnu interakciju roditelja/skrbnika i odgajatelja. Ona se očituje u otvorenoj, podržavajućoj i ravnopravnoj komunikaciji u kojoj svatko od sugovornika, svojstveno svojemu zvanju i odgovornostima, doprinosi kvalitetnomu partnerskomu odnosu. On se ne iscrpljuje u razmjeni informacija o djetetu, iako je to jedan od najčešćih sadržaja komunikacije između roditelja i odgojitelja, nego se razvija tako da omogućuje primjereno i usklađeno odgojno-obrazovno djelovanje usmjereno djetetovoj dugoročnoj dobrobiti. 
Izgradnji suradničkoga odnosa na poseban način doprinose kompetencije odgojitelja, koji trebaju biti senzibilizirani za prepoznavanje specifičnih potreba roditelja/skrbnika kako bi ih podržali i osnažili u roditeljskoj ulozi te ih potaknuli na uključenje u zajedničko donošenje odluka vezanih uz cjelovit razvoj njihova djeteta. S tim ciljem u Nacionalnom kurikulumu za rani i predškolski odgoj $i$ obrazovanje istaknuto je kako se kvalitetan partnerski odnos odgojitelja i roditelja/skrbnika djece ostvaruje u uvjetima u kojima je roditeljima/skrbnicima djece omogućeno provođenje vremena sa svojom djecom u odgojnim skupinama, $\mathrm{tj}$. praćenje i djelatno sudjelovanje u neposrednom odgojno-obrazovnom procesu. Osim toga, istaknuto je da roditelje treba poticati na sudjelovanje u oblikovanju vizije ustanove te im omogućiti sudjelovanje u planiranju, realiziranju i evaluaciji odgojno-obrazovnoga procesa. Time se roditeljima omogućuje da budu uistinu partneri, promotori odgojno-obrazovnoga procesa, ali i posrednici u senzibiliziranju lokalne i šire društvene zajednice. Kvalitetna suradnja odgojitelja i roditelja/skrbnika nužna je, te ima dakle višestruki učinak i dalekosežne posljedice, a jedna je i od pretpostavki za osiguravanje kontinuiteta u odgoju i obrazovanju (Slunjski et al., 2014, 15).

Postoje neke specifičnosti po kojima se suradnja roditelja i odgojitelja može razlikovati u javnim, privatnim i katoličkim dječjim vrtićima. Namjera nam je istaknuti baš neke polazišne specifičnosti u suradnji s roditeljima u katoličkim dječjim vrtićima.

\subsection{Neke specifičnosti u suradnji s roditeljima u katoličkim dječjim vrtićima}

Preporuke o ostvarivanju kvalitetne suradnje između roditelja i odgojitelja obvezuju sve dječje vrtiće. U konkretnoj odgojno-obrazovnoj praksi, te opsegu, oblicima i samoj kvaliteti uspostavljene suradnje moguća su očitovanja nekih specifičnosti s obzirom na to je li riječ o javnom državnom, privatnom ili katoličkom dječjem vrtiću. U dječjim vrtićima kojima su osnivači katoličke vjerske zajednice, tj. družbe sestara ili župe, specifičnosti proizlaze iz same naravi katoličkoga odgoja i obrazovanja, koji ide »za izgradnjom ljudske osobe u vidu njezine konačne svrhe i ujedno u vidu dobrobiti društva kojega je čovjek član i u čijim će funkcijama kao odrasli čovjek sudjelovati« (GE 1). Tu svrhu nemoguće je ostvarivati bez roditelja koje Crkva priznaje »prvim i povlaštenim odgojiteljima svoje djece«(GE 3). Isticanje roditeljske uloge u odgoju i obrazovanju djece, pa i u predškolskim ustanovama, u katoličkom se kontekstu temelji na nekim osnovama koje sežu mnogo dalje i dublje od onih koje donose pravne norme (Eterović, 2001, 206-209). Iako su pravni okviri važni, oni redovito služe nekim drugim ciljevima, a ne toliko motivacijskoj snazi djelovanja osoba kojih se tiču. Pravna određenja i definiranje dužnosti nisu kadri motivirati djelovanja onoliko koliko su to kadra temeljna shvaćanja vlastitoga životnoga poziva. Potrebu odgojne suradnje, u kontekstu odgoja u katoličkom duhu, nije moguće opravdavati isključivo odozdo. Ona pronalazi svoj izvor u nadnaravnoj objavi koja proizlazi od teološkoga poimanja, u ovom slučaju roditeljskoga poziva, čija je konstitutivna funkcija i ona odgojna (AL 259). Odgoj i obrazovanje u tom smislu u službi su 
ostvarivanja čovjekove konačne svrhe, a ta je pozvanost u zajedništvo s Bogom is ljudima (CCE 1878). Takvo poimanje čovjekove egzistencije, ukoliko je shvaćeno u dubini značenja i prihvaćeno u svim aspektima odgojno-obrazovne prakse, obuhvaća i istovremeno nadilazi definiranje konačnoga cilja odgoja kakvoga nam donose aktualni dokumenti koji su obvezujući u svim segmentima odgojno-obrazovnoga sustava.

Odgoj i obrazovanje u katoličkim ustanovama ide zasigurno za tim da služi dobrobiti djece i njihovoj kompetentnosti, i to baš zato što u središte stavlja vrijednosnu kategoriju zajedništva zasnovanoga u ljubavi (DV 2). U katoličkim odgojno-obrazovnim ustanovama suradnja roditelja i odgojitelja temelji se, dakle, na osnovi koja je puno snažnija od one koju nam donosi potreba partnerstva radi dobrobiti djeteta shvaćenoga u isključivo horizontalnom poimanju egzistencije. Ta osnova je sakramentalna i smjera ostvarivanju suradničkih odnosa na svim razinama kako bi se roditelje osnažilo i pomoglo u izvršavanju njihove odgojne zadaće, koja je danas uvelike otežana (AL 50, 85 i 287). U katoličkom kontekstu se stoga prvenstveno ističe potreba potpore i asistencije (AL 279). Bilo kakav oblik zamjenske uloge koja bi isključivala prvenstvo roditeljske odgojne funkcije ne smatra se dobrom impostacijom suradničkih odnosa, nego preprekom kvalitetne suradnje, koja u konačnici rezultira cijelim nizom negativnih posljedica, ponajprije za dijete.

Navedene naglaske trebala bi uvažavati odgojno-obrazovna praksa u katoličkim vrtićima, čiji je konstitutivni dio vjerski odgoj. Prema dokumentima koji opisuju koncept odgojno-obrazovnoga rada u katoličkim predškolskim ustanovama, taj jedinstveni proces odgoja i obrazovanja ima humanističko polazište, a obilježava ga otvorenost prema vjerskomu horizontu, koji odgovara opće poznatomu načelu religiozne pedagogije, tj. zahtjevu vjernosti Bogu i vjernosti osobi (DGC 139-140; Hoblaj, 2006, 36-39). Taj se program razlikuje od onih koji odgoj i obrazovanje određuju isključivo prema funkcionalnoj paradigmi, jer se u konačnici očituje kao pomoć koja ima za zadatak osposobiti dijete za život, što pozitivnije i bogatije proživljavanje vlastitosti svoje dobi (Napolioni, 1998, 83). Jedno od načela koji ga obilježavaju glasi: »Ništa raditi bez roditelja « (Hrvatska biskupska konferencija, 1994, 33). To načelo usko je povezano s ciljem i zadaćama katoličkoga odgoja koji smjeraju otkrivanju, prihvaćanju i življenju autentičnih vrijednosti evanđelja (Hrvatska biskupska konferencija, 2015, 7-8). S ciljem usklađenosti odgojno-obrazovnoga djelovanja u aktualnom programu vjerskoga odgoja stoga se ističe potreba razvoja suradnje s roditeljima individualnim razgovorima, na roditeljskim sastancima, uključivanjem roditelja u projekte i druge aktivnosti odgojne skupine, formiranjem kutića za roditelje (informativni i edukativni), programskom suradnjom (sudjelovanje za blagdane), radionicama te posjetima obiteljima (Hrvatska biskupska konferencija, 2015, 20). Budući da roditelji prema vlastitom izboru svoju djecu upisuju u katoličke dječje vrtiće, za očekivati je da će se suradnja između roditelja i odgojitelja u tim ustanovama razvijati u većoj usklađenosti jer se temelji na obostrano prihvaćenoj ljestvici vrijednosti (Alathara, 2005, 110). Iz uvjerenosti da je po njoj moguće živjeti dostojan- 
stveno, tj. sukladno svojoj konačnoj svrsi, roditelji i odgojitelji ju žele prenijeti i djeci, poštujući pritom odgovornosti koje su im vlastite, dakle različite, ali i bitno komplementarne (FC 37-40).

\section{Istraživanje učestalosti i oblika suradnje odgojitelja i roditelja $u$ katoličkim, javnim i privatnim dječjim vrtićima}

\subsection{Metodologija istraživanja}

U istraživanju se krenulo od Epsteinove teorije preklapajućih sfera utjecaja (Epstein, 2001, 34), a prema kojoj dijete živi u tri bitna konteksta: u obitelji, odgojno-obrazovnoj ustanovi i društvenoj zajednici. Prema Epsteinu, neke su aktivnosti poticanja razvoja djece koje poduzimaju obitelji, ustanove i zajednica usuglašene i koordinirane, a druge se aktivnosti provode odvojeno i nepovezano. Epstein se zalaže za aktivno sudjelovanje roditelja u djelatnosti odgojno-obrazovne ustanove, pa predlaže šest vrsta roditeljske uključenosti: pomoć roditeljima u roditeljstvu; komunikacija između roditelja i odgojitelja; volontiranje roditelja u predškolskim ustanovama; pomoć roditeljima u poticanju učenja djeteta kod kuće; sudjelovanje roditelja u donošenju odluka te uključenost roditelja u suradnju s lokalnom zajednicom.

U istraživanju je korištena kvalitativna istraživačka paradigma. Cilj istraživanja bio je usmjeren prema ispitivanju odgojiteljevih iskustava o oblicima i učestalosti suradnje s roditeljima. S ciljem prikupljanja podataka korišten je polustrukturirani intervju koji je tematski polazio od Epsteinova modela partnerstva.

Odabran je mali nereprezentativni uzorak ispitanika od devet odgojiteljica. Istraživanje je provedeno u tri javna, tri katolička i tri privatna dječja vrtića. Istraživanje je provedeno u dječjim vrtićima na području Zadarske županije.

\subsection{Rezultati istraživanja i rasprava}

Analizirajući odgovore ispitanika u vezi s odgojiteljevom pomoći roditeljima u roditeljstvu, ustanovljeno je kako se u dječjim vrtićima tijekom pedagoške godine organiziraju jednom ili dva puta godišnje predavanja za roditelje. Roditelji također mogu svakodnevno dobiti informacije o postignućima i ponašanjima djece, a i odgojitelji često traže od roditelja informacije o djetetu, njegovim osobinama, sposobnostima i interesima. S obzirom na osnivače dječjega vrtića, ne uočava se razlika u toj dimenziji partnerstva.

Ispitanici su izrekli i svoja iskustva o komunikaciji s roditeljima, odnosno najčešćih oblika komuniciranja s roditeljima. Od različitih oblika komuniciranja s roditeljima, odgojitelji najčešće vode kratke individualne razgovore s roditeljima prilikom dovođenja i odvođenja djece iz vrtića. Prema izjavama odgojitelja, roditelji imaju mogućnost svakodnevnoga uvida u dječje radove i mape, a omogućena im je komunikacija telefonom i e-poštom s odgojiteljima, kao i komunikacija na zajedničkim Facebook stranicama. Tijekom godine organiziraju se i roditeljski sastanci radi pružanja informacija roditeljima o programu djelatnosti, događa- 
njima u ustanovi i sl. S obzirom na osnivače dječjih vrtića, moguće je uočiti kako na odabranom uzorku ispitanika telefonski najčešće s roditeljima komuniciraju odgojitelji iz privatnih dječjih vrtića. Odgojitelji iz javnih i privatnih dječjih vrtića također izjavljuju kako često koriste komunikaciju s roditeljima putem e-pošte i Facebooka. Odgojitelji koji rade u katoličkim dječjim vrtićima izjavljuju kako im je najučestaliji oblik komunikacije s roditeljima, osim svakodnevnih individualnih razgovora, redoviti mjesečni roditeljski sastanak.

Ispitanici su se izjasnili i o uključivanju roditelja u različite oblike volontiranja. Zanimljivo je uočiti kako je zanimanje roditelja prema volonterskom radu u dječjem vrtiću jednako, bez obzira na osnivača dječjega vrtića. Prema mišljenju ispitanika, veći broj roditelja iskazuje otvorenost prema volontiranju u predškolskoj ustanovi. Na pitanje o vrstama aktivnosti u koje se roditelji najčešće uključuju, u javnim dječjim vrtićima dobili smo sljedeće odgovore: u prezentiranju svojih zanimanja; u sportskim aktivnostima; u organizaciji izleta; sudjelovanjem s odgojiteljima u realizaciji izravnoga rada s djecom. U privatnim dječjim vrtićima roditelji, prema izjavama odgojiteljica, rado sudjeluju u aktivnostima Želim biti teta jedan dan, u skupljanju sredstava za humanitarne akcije, kao i u organizaciji predstava i karnevalskih svečanosti. U katoličkim dječjim vrtićima roditelji se žele volonterski uključiti u organizaciju izleta i svečanosti, organizaciju posjeta kulturnim ustanovama, prezentaciju svojih zanimanja, kao i u vjerske aktivnosti dječjega vrtića i pripadajuće župe. Kako bi se omogućilo uključivanje roditelja u djelatnosti dječjega vrtića, potrebo im je osigurati i adekvatan prostor za međusobno druženje i boravak. Stoga su nam ispitanici odgovorili na upit o raspoloživosti posebne prostorije za roditelje u prostorima dječjega vrtića. Na ispitanom uzorku posebna prostorija za potrebe roditelja postoji samo u katoličkim dječjim vrtićima.

U dimenziji pomoći roditeljima u poticanju učenja djeteta kod kuće ispitanici su se izjasnili o dvama pitanjima: Dobivaju li roditelji informacije / materijale kako kod kuce poticati razvoj djeteta te unaprjeđivati djetetove kompetencije? Pomažete li roditeljima u odabiru različitih izvanvrtićkih aktivnosti za dijete? Svi su ispitanici na prvo pitanje odgovorili kako često pružaju roditeljima informacije o mogućem poticanju razvoja kompetencija djece u obiteljskom okruženju. Međutim, odgovori ispitanika na drugo pitanje razlikovali su se. U tom uzorku ispitanika odgojitelji koji rade u katoličkim dječjim vrtićima, a u odnosu na druge dvije kategorije odgojitelja, redovito su pomagali roditeljima u odabiru izvanvrtićkih aktivnosti za njihovu djecu.

Jedna od dimenzija partnerstva roditelja i odgojitelja jest mogućnost sudjelovanja roditelja u donošenju odluka u dječjem vrtiću. Tu dimenziju partnerstva ispitali smo pomoću sljedećih čestica: poznavanje predstavnika roditelja u upravnom vijeću dječjega vrtića; uključenost roditelja u planiranje odgojno-obrazovne djelatnosti; uključenost roditelja u procese donošenja odluka u vezi s drugim aspektima realizacije kurikuluma. Temeljem izjava ispitanika moguće je zaključiti kako odgojiteljice, neovisno o osnivaču dječjeg vrtića, izjavljuju kako ne znaju tko je predstavnik roditelja u tijelu uprave. Nitko od odgojiteljica ne navodi je 
li roditeljima omogućeno da sudjeluju u donošenju odluka o uređenju prostora, nabavki opreme, realizaciji projekata i sl. Sudjelovanjem roditelja u donošenju odluka doprinijelo bi se razvoju osjećaja njihove kompetentnosti i važne uloge $u$ odgoju djece (Bruckman i Blanton, 2003, 147).

Ispitanici su iznijeli i svoja iskustva o uključenosti roditelja u suradnju s lokalnom zajednicom, odnosno u aktivnosti koje dječji vrtić organizira zajedno s kulturnim, vjerskim i sportskim ustanovama u lokalnom okruženju. Prema odgovorima odgojiteljica, većina se roditelja često uključuje u zajedničke aktivnosti koje organiziraju dječji vrtić i ustanove u lokalnoj zajednici. Međutim, jedan manji dio roditelja uključuje ne se u zajedničke aktivnosti. Dobivene se informacije o uključenosti roditelja ne razlikuju s obzirom na osnivača dječjega vrtića. Izuzetak čine roditelji djece koja pohađaju katoličke dječje vrtiće i koji se redovitije uključuju u zajedničke aktivnosti župe i katoličkoga vrtića. Lokalna zajednica treba nuditi raznovrsne programe i aktivnosti za djecu, roditelje i odgojitelje, »a ponuđene programe valja temeljiti na potrebama njihovih korisnika« (Nenadić-Bilan i Matov, 2014, 127)

Intervjuirani odgojitelji iznijeli su i prepreke s kojima se suočavaju u realizaciji partnerskih odnosa s roditeljima. Naime, sve odgojiteljice izjavljuju kako je prezaposlenost roditelja te nepodudaranje njihova radnoga vremena s vremenom održavanja zajedničkih aktivnosti ili susreta temeljna prepreka u boljem odazivu roditelja. Slične prepreke u ostvarivanju suradnje nalazimo i u drugim socio-kulturnim kontekstima. Tako istraživanje Veisson et al. $(2010,49)$ pokazuje kako većina roditelja u Estoniji, Finskoj, Islandu i Portugalu izjavljuje da je nedostatak vremena najveća prepreka u njihovom aktivnijem uključivanju u suradnju s odgojiteljima.

Sve odgojiteljice u ispitanom uzorku izjavljuju kako su uglavnom zadovoljne postignutom kvalitetom suradnje s roditeljima te smatraju da ih roditelji prihvaćaju kao suradnike.

\section{Zaključak}

Mali nereprezentativni uzorak ne omogućava donošenje konačnih zaključaka, kao ni uopćavanje, ali potiče na potrebu dublje analize uočenih pojavnosti. Naime, izjave intervjuiranih odgojiteljica ukazuju na neke sličnosti u dimenzijama realizacije partnerskih odnosa u svim dječjim vrtićima, bez obzira na osnivača ustanove. To se prvenstveno odnosi na odgovore ispitanika o odgojiteljevoj pomoći roditeljima u roditeljstvu, uključivanju roditelja u različite oblike volontiranja te na mogućnosti sudjelovanja roditelja u donošenju odluka u dječjem vrtiću.

$\mathrm{S}$ obzirom na različite oblike komunikacije s roditeljima, odgojiteljice koje rade u javnim i privatnim dječjim vrtićima sklonije su komunicirati s roditeljima putem e-pošte i Facebooka, a odgojiteljice u katoličkim dječjim vrtićima češće komuniciraju svakodnevno s roditeljima tijekom individualnih susreta s roditeljima te na redovitim mjesečnim sastancima. Roditelji se, prema mišljenju odgojiteljica, ne razlikuju s obzirom na uključivanje u različite aktivnosti volontiranja. 
Izuzetak čine roditelji djece koja pohađaju katoličke dječje vrtiće, a koji se češće uključuju u vjerske aktivnosti vrtića. Posebna prostorija za susrete i potrebe roditelja postoji samo u katoličkim dječjim vrtićima. U dimenziji pomoći roditeljima odgovori ispitanika na pitanje pomažu li roditeljima u odabiru različitih izvanvrtićkih aktivnosti razlikovali su se. U tom uzorku ispitanika odgojiteljice koji rade u katoličkim dječjim vrtićima izjavljuju, u odnosu na druge dvije skupine odgojiteljica, kako redovito pomažu roditeljima u odabiru izvanvrtićkih programa. U vezi s uključenosti roditelja u suradnju s lokalnom zajednicom, jedan manji dio roditelja ne uključuje se u zajedničke aktivnosti na razini lokalne zajednice, a navedeni podatak se ne razlikuje s obzirom na osnivača ustanove. Izuzetak čine roditelji djece koja pohađaju katoličke dječje vrtiće, koji se redovitije uključuju u zajedničke aktivnosti župe.

U usporedbi s javnim i privatnim vrtićima, u katoličkim dječjim vrtićima odgojiteljice izjavljuju kako su sklonije usmenoj komunikaciji s roditeljima, i to tijekom svakodnevnih individualnih razgovora s roditeljima te na redovitim mjesečnim sastancima. Iste odgojiteljice navode kako redovito pomažu roditeljima u odabiru izvanvrtićkih aktivnosti za djecu. Roditelji djece koja pohađaju katolički dječji vrtić, prema mišljenju njihovih odgojiteljica, češće se uključuju u volontiranje u vjerskim aktivnostima na razini predškolske ustanove, kao i lokalne zajednice. U katoličkom dječjem vrtiću postoji posebna soba za međusobne sastanke, druženja i dogovaranja. Ukazuju li uočene razlike na izvjesnu sklonost njegovanja zajedništva u katoličkim dječjim vrtićima? U nekim budućim istraživanjima bilo bi zanimljivo provjeriti zamijećenu tendenciju.

\section{Literatura:}

AL. Amoris laetitia. Franjo, Amoris laetitia: Radost ljubavi: Posinodalna apostolska pobudnica biskupima, prezbiterima i đakonima, posvećenim osobama, kršćanskim supruzima i svim vjernicima laicima o ljubavi u obitelji. Zagreb: Kršćanska sadašnjost.

Alathara, Stephen (2005). Introduction to Catechetics. Bangalore: ATC.

Australian Children's Education and Care Quality Authority (2016). Building Partnerships with Families. Sydney: Australian Children's Education and Care Quality Authority.

Balaić, Siniša (2011). Životno zajedništvo i dinamika odnosa u svjetlu prispodobe o izgubljenom sinu. Služba Božja, 51(3-4), 350-364.

Bruckman, Marylin; Blanton, Priscilla (2003). Welfare-to-work Single Mothers' Perspecitves on Parent Involvement in Head Start: Implications for Parent-teacher Collaboration. Early Childhood Educational Journal, 30(3), 145-150.

CCE. Catechismus Catholicae Ecclesiae. Ivan Pavao II., Katekizam Katoličke crkve: Dorađeno izdanje. Zagreb: Hrvatska biskupska konferencija, 2016.

DGC. Direttorio Generale per la Catechesi. Kongregacija za kler, Opći direktorij za katehe$z u$. Zagreb: Kršćanska sadašnjost, 2000.

DV. Dei verbum. Drugi vatikanski koncil, Dogmatska konstitucija Dei verbum o božanskoj objavi. U: Josip Turčinović (ur.), II vatikanski koncil: Dokumenti: Latinski i hrvatski (str. 392-416). Zagreb: Kršćanska sadašnjost, 1970.

Epstein, Joyce (2001). School, family and Community Partnerships: Preparing Educators and Improving Schools. Boulder: Westview. 
Eterović, Nikola (2001). Ugovor između Svete Stolice i Republike Hrvatske o suradnji na području odgoja i kulture. U: Nedjeljko Pintarić (ur.), Ugovori između Svete Stolice i Republike Hrvatske (str. 203-257). Zagreb: Glas Koncila.

FC. Familiaris consortio. Ivan Pavao II., Familiaris consortio: Obiteljska zajednica: Apostolska pobudnica o zadaćama kršćanske obitelji u suvremenom svijetu. Zagreb: Kršćanska sadašnjost, 2009.

Fuchs, Radovan; Vican, Dijana; Milanović Litre, Ivan (ur.) (2011). Nacionalni okvirni kurikulum za predškolski odgoj i obrazovanje te opće obvezno i srednjoškolsko obrazovanje. Zagreb: Ministarstvo znanosti, obrazovanja i športa,.

GE. Gravissimum educationis. (28. listopada 1965.) Drugi vatikanski koncil, Deklaracija Gravissimum educationis o kršćanskom odgoju. U: Josip Turčinović (ur.), II vatikanski koncil: Dokumenti: Latinski i hrvatski (str. 360-380). Zagreb: Kršćanska sadašnjost, 1970.

Hargrave, Terry; Jennings, Glen; Anderson, William (2007). The Development of a Relational Ethics Scale. Journal of Marital and Family Therapy, 17(2), 145-158.

Heinrich, Christopher (2013). Commentary on the Special Issue on Parent Involvement: Engagement in Early Childhood Education. Dialog, 16(1), 253-258.

Hoblaj, Alojzije (2006). Teološko-katehetska ishodišta vjerskoga odgoja u ranom djetinjstvu. Zagreb: Glas Koncila.

Hrvatska biskupska konferencija (1994). Program vjerskog odgoja predškolske djece u izvanobiteljskim uvjetima. Zagreb: Glas Koncila.

Hrvatska biskupska konferencija (2015). Program katoličkoga vjerskog odgoja djece rane $i$ predškolske dobi: Obnovljeno i dopunjeno izdanje. Zagreb: Nacionalni katehetski ured Hrvatske biskupske konferencije.

Ljubetić, Maja (2014). Od suradnje do partnerstva obitelji, odgojno-obrazovne ustanove $i$ zajednice. Zagreb: Element.

Napolioni, Antonio (1998). Grandi come bambini. Torino: Elledici.

Nenadić-Bilan, Diana; Matov, Jadranka (2015). Partnerstvo obitelji i predškolske ustanove kao potpora roditeljstvu. Magistra Iadertina, 9(1),123-135.

Oostdam, Ron; Hooge, Edith (2013). Making the Difference with Active Parenting: Forming Educational Partnerships between Parents and Schools. European Journal of Psychology of Education, 28(2), 337-351.

Peterson, Chris (2006). A Primer in Positive Psychology. New York: Oxford University.

Rolnick, Philip (2012). Osoba, milost i Bog. Zagreb: Kršćanska sadašnjost.

Slunjski, Edita; Ljubetić, Maja; Pribela Hodap, Sonja; Malnar, Ana; Kljenak, Tatjana; Zagrajski Malek, Snježana; Horvatić, Sanja; Antulić, Sandra (2012). Priručnik za samovrednovanje ustanova ranog i predškolskog odgoja i obrazovanja. Zagreb: Nacionalni centar za vanjsko vrednovanje obrazovanja

Slunjski, Edita; Vujičić, Lidija; Burić, Helena; Jaman-Čuveljak, Kamea; Pavlic, Karmen; Franko, Ana; Plaza Leutar, Mara; Guštin, Davorka; Drviš, Darija (2014). Nacionalni kurikulum za rani i predškolski odgoj i obrazovanje. Zagreb: Ministarstvo znanosti, obrazovanja i sporta.

Veisson, Marika; Einarsdóttir, Jonina; Garõarsdóttir, Ben; Gaspar, Maria; Hujala, Eeva; Suur, S. (2010). A Cross-cultural Qualitative Study on Parent-teacher Partnerships in Child Care in Estonia, Finland, Iceland and Portugal. U: J. Mikk, M. Veisson i P. Luik (ur.). Estonian Studies in Education (str. 31-52). Frankfurt: Peter Lang.

Vincent, Carol (1996). Parents and Teachers: Powers and Participation. London: Routledge.

Wit, Cees de (2005). Ouders als educatieve partner. Den Haag: Q*Primair. 
The Frequency and Forms of Cooperation between Preschool Teachers and Parents in Catholic Kindergartens with respect to Public and Private Kindergartens in Zadar County

\section{Marijana Mohorić*, Diana Nenadić-Bilan** \\ Summary}

Starting with the need for active and intensive parental involvement in achieving the goal of early childhood education, the paper presents the results of research on the frequency and forms of partnership between parents and preschool teachers. Data was collected using a semi-structured interview based on Epstein's model of partnership. Research was conducted on a sample of three city public kindergartens, three private kindergartens and three Catholic kindergartens in Zadar County, Croatia. The findings suggest that, regardless of the founders of the kindergartens, there are similarities in the attitudes of the respondents regarding the three forms of partnership - parenting, volunteering, and decision-making. Differences are noted in regard to other forms of parental involvement - communicating, at-home learning, and collaborating with the community.

Key words: cooperation, parents, preschool teachers, Catholic kindergartens

* Mr.sc. Marijana Mohorić, University of Zadar, Department of Religious Sciences. Address: Dr. Franje Tuđmana 24i, 23000 Zadar, Croatia. E-mail: marijana.scj@gmail.com

** Diana Nenadić-Bilan, Ph.D., Assistant Professor, University of Zadar, Department of Teacher and Preschool Teacher Education. Address: Dr. Franje Tuđmana 24i, 23000 Zadar, Croatia. E-mail: dnbilan@gmail.com 